\title{
ВОЛЬОВІ ЯКОСТІ АВАНТЮРНИХ І НЕАВАНТЮРНИХ ОСІБ
}

\author{
Наталя Меленчук \\ кандидат психологічних наук, старший викладач кафедри загальної та \\ диференціальної психології \\ Південноукраїнський національний педагогічний університет імені К.Д. Ушинського \\ 65020, Україна, м. Одеса, вул. Старопортофранківська, 26 \\ Natmelenchuk0808@gmail.com, http://orcid.org/0000-0002-4749-6889
}

\begin{abstract}
Анотація
Здійснено теоретичний аналіз досліджень щодо визначення таких феноменів, як: «авантюрність», «авантюра», «авантюризм». Авантюрність (схильність до авантюрної поведінки) як складна властивість особистості, розглядається 3 позицій континуальноієрархічного підходу до структури особистості. Актуальність розробки проблеми пов'язана 3 потребою вивчення вольових якостей та властивостей особистості, котрі вимагають сміливих, швидких, ризикованих і авантюрних дій в умовах високої невизначеності. Для емпіричної перевірки було обрано: оригінальний психодіагностичний «Тест-опитувальник схильності до авантюрності» (АВАНТ-1)» О.П. Саннікової, О.І. Саннікова, Н.I. Меленчук і методику «Вольові якості особистості» М.В. Чумакова. Подано результати кореляційного аналізу між показниками авантюрності й вольових рис особистості. Встановлено переважно додатні значимі кореляційні взаємозв'язки між всіма показниками авантюрності та більшістю показників вольових якостей особистості, а, саме, з показниками рішучість (Rsh), ініціативність (In), самостійність (Sm) і наполегливість (Np). Виняток становлять показники відповідальність $(\mathrm{Vd})$ і цілеспрямованість $(\mathrm{Cl})$, з якими виявлено від'ємні значимі зв'язки. На основі якісного аналізу емпіричних даних вивчено специфіку вольових якостей особистості в «авантюрних» i «неавантюрних» осіб. Показано, що авантюрні особистості, порівняно 3 неавантюрними, більш рішучі, самостійні, ініціативні, наполегливі. Їм властива впевненість, незалежність, сміливість, рішучість, самостійність, висока креативність, продуктивність і наполегливість у досягненні своєї мети. Виявлено, що неавантюрні особистості, на відміну від авантюрних осіб, більш відповідальні, цілеспрямовані. Отримані результати засвідчують, що в авантюрних осіб рівень свідомої регуляції поведінки, іiі влади над собою більш виражений, ніж у осіб з низьким рівнем авантюрності.
\end{abstract}

Ключові слова: авантюрність, схильність до авантюрної поведінки, вольові якості особистості, властивість особистості, кількісний аналіз, якісний аналіз.

\section{Ветуп}

Сучасне суспільство, постійні соціально-економічні трансформації вимагають від особистості активності, сміливості, впевненості, відкритості, самовираження й саморозвитку. Вагоме місце серед цих проявів займає здатність особистості до саморегуляції, ризикованих і авантюрних дій в умовах високої невизначеності. Ризик в житті людини відіграє особливу роль. Кожна людина в своєму житті в окремих ситуаціях, тим чи іншим чином ризикує, задля отримання бажаного результату. Для деяких людей ризик - це невід’ємна частина життя, що сприяє отриманню незабутніх емоцій, перевірки себе на міцність, прояву авантюризму. 
Водночас особистість повинна вміти усвідомлювати і скеровувати свою поведінку, ефективно долати труднощі, які зустрічаються їй на шляху досягнення мети. Таку регуляцію забезпечує вольова сфера особистості.

Авантюрність є досить багатогранним явищем, яке можна розглядати з різних, а іноді й із протилежних позицій.

В широкій асоціативності терміну цілком розсіявся його більш-менш точний зміст. Необхідно відрізняти «авантюрну особистість» від людини, яка володіє «авантюрною жилкою», «любов'ю до авантюри» тощо. Важливо відзначити, що авантюризм не є тим, 3 чим його досить часто плутають в побутовому дискурсі. А саме, авантюризм - це не аферизм, не шахрайство і не шарлатанство. Думаємо, що, навпаки, професійний авантюризм вимагає дуже високої якості професіоналізму й навичок в самих різних теоретичних i практичних дисциплінах, широкого кругозору, виходу за межі конвенціональної моралі та здатності приймати й ототожнюватися із самими різними, іноді протилежними, точками зору, ідеями і навіть ідеологіями. I, звичайно ж, це - здатність до ризику (Меленчук, 2016).

Найбільш поширеним визначенням поняття «авантюра», що зустрічається в багатьох психологічних словниках, є: «Авантюра - це ризикований, непевний захід, дія, справа, що розпочата без урахування реальних сил і умов, в розрахунку на випадковий успіх; це легковажний вчинок або ряд вчинків, що здійснюється заради отримання задоволення, розваг; пригода». Сам термін «авантюра» французького походження - «aventurier», що перекладається, як «пригода»; 3 латинської «adventura» - «траплятися», «відбуватися», «3’являтися», «наступати», «прибувати» (Бусел, 2005: 4; Евгеньев, 1981: 20-21).

«Авантюризм» в літературі розуміється як схильність до ризикованих, сумнівних заходів, пригод, що мотивована виключно чи переважно потребою в чуттєвому різноманітті, в яскравих враженнях, у гострих відчуттях, а нерідко також в популярності та славі (Жмуров, 2010). Це поведінка, діяльність, що характеризується ризикованими, безпринципними вчинками заради досягнення легкого успіху, вигоди; схильність до авантюр. Натомість «авантюрист» визначається як шукач пригод, той, хто схильний до авантюризму; «безпринципний ділок»; пройдисвіт (Бусел, 2005: 4; Жмуров, 2010; Санникова, 1995: 20-21).

Сьогодні окремі характеристики авантюрності розглядаються крізь призму позитивної психології. Так, Houge Mackenzie \& S. Brymer виявили, що пригодницькі види спорту вибирають особистості з гедоністичними тенденціями, які мотивовані виключно прийняттям ризику, що властиво й представникам авантюрного типу (Houge Mackenzie \& Brymer, 2020).

В деяких дослідженнях використовується «пригодницька терапія», яка заснована на активному відпочинку на природі й на навчанні ризику. Цей вид терапії застосовується для профілактики та лікування людей, переважно молоді, з поведінковими, психологічними та психосоціальними проблемами (Bowen, Neill \& Crisp, 2016).

Авантюрність (схильність до авантюрної поведінки) в цій праці розуміється як складна багаторівнева властивість особистості, психологічна сутність якої виявляється у надії на легкий і швидкий успіх, вдачу при наявності кінцевої мети, що є принадливою для особистості, без ретельного аналізу реальних зовнішніх обставин, власних можливостей (ресурсів), шляхів вирішення проблеми задля досягнення мети (Меленчук, 2016; Саннікова, Санніков \& Меленчук, 2015; Sannikova, Melenchuk \& Sannikov, 2021) .

Окремі автори виділяють комплекс рис особистості, який впливає на схильність до авантюрної поведінки людини, також як і ситуації, що провокують авантюрну поведінку. Так, встановлено, що люди 3 високим рівнем агресивності, 3 сильною потребою в 
домінуванні й самоствердженні, більш схильні до авантюрних вчинків (Меленчук, 2016; Олдхэм \& Моррис, 1996). До рис авантюрної особистості відносять екстремально виражену спрагу домінувати над іншими людьми. Крім цього, зазначають, що таким людям властиві погане самоврядування, впевненість, імпульсивність, ініціативність, рішучість, активність, ризикованість (Roth, 1980).

Тому метою нашого дослідження було обрано вивчення особливостей проявів вольових якостей в осіб з різним рівнем авантюрності. Завдання дослідження: 1) на основі теоретико-методологічного аналізу наукових джерел уточнити сутність феноменів «схильність до авантюрної поведінки» («авантюрність») і «вольові якості особистості»; 2) підібрати комплекс валідних і надійних психодіагностичних методик, що спрямований на діагностику авантюрності й вольових якостей особистості та емпірично визначити характер їх співвідношень; 3) дослідити специфіку проявів вольових якостей осіб, схильних до авантюрної поведінки різного ступеня.

\section{Методи дослідження}

Відповідно до мети дослідження нами були обрані такі психодіагностичні методики:

- для діагностики авантюрності застосовувався «Тест-опитувальник схильності до авантюрності» (АВАНТ-1) О.П. Саннікової, О.І. Саннікова, Н.І. Меленчук (Саннікова, Санніков, \& Меленчук, 2015; Sannikova, Melenchuk \& Sannikov, 2021);

- для вивчення вольових якостей особистості використовувався питальник «Вольові якості особистості» М.В. Чумакова. Питальник спрямований на діагностику загального показника волі й таких вольових якостей, як: відповідальність, ініціативність, рішучість, самостійність, витримка, наполегливість, енергійність, уважність, цілеспрямованість (Чумаков, 2006; Чумаков, 2009).

Вибірку склало 102 досліджуваних віком 24-45 рр. (магістри заочної та денної форм навчання відділення перепідготовки фахівців за магістерською програмою 3 психології Державного закладу «Південноукраїнський національний університет ім. К.Д. Ушинського»).

Статистична обробка здійснювалась за допомогою комп'ютерної програми SPSS 13.0 for Windows. Використовувались кількісний (кореляційний) та якісний (метод «профілів» i метод «асів») аналіз даних. Застосування кількісного аналізу дозволило знайти взаємозв'язки між всіма показниками, що вивчалися. Використання якісного аналізу сприяло вивченню особливостей прояву вольових якостей досліджуваних із різним рівнем авантюрності.

\section{Результати та дискусії}

Для з'ясування статистичних зв'язків між показниками авантюрності та комунікативної креативності було проведено кореляційний аналіз. Аналіз кореляцій показав наявність значної кількості значимих додатних і від'ємних зв'язків. Розглянемо отримані зв’язки більш детально. Результати кореляційного аналізу презентовано в табл. 1.

Показник відповідальність (Vp) встановив від'ємні значимі зв'язки з установчим (AvUst) i емоційно-мотиваційним показником (AvEM) авантюрності на 1\% рівні, та загальним показником схильності до авантюрності (AvOb) - на 5\% рівні. Отримані результати свідчать про те, що авантюрність характеризується слабкою відповідальністю, необов'язковістю, недисциплінованістю та недбалістю. 
Значимі коефіціснти кореляцій між показниками авантюрності та показниками вольових якостей особистості

\begin{tabular}{|l|c|c|c|c|c|c|}
\hline \multirow{2}{*}{$\begin{array}{c}\text { Показники } \\
\text { вольових якостей } \\
\text { особистості }\end{array}$} & \multicolumn{5}{|c|}{ Показники авантюрності } \\
\cline { 2 - 7 } & AvUst & AvEM & AvKk & AvErg & AvKr & AvOb \\
\hline $\mathrm{Vp}$ & $-0,292^{* *}$ & $-0,363^{* *}$ & & & & $-0,231^{*}$ \\
\hline $\mathrm{In}$ & & $0,243^{*}$ & & & & \\
\hline $\mathrm{Rsh}$ & & $0,334^{* *}$ & & $0,232^{*}$ & $0,395^{* *}$ & $0,262^{*}$ \\
\hline $\mathrm{Sp}$ & & $0,237^{*}$ & & $0,326^{*}$ & & \\
\hline $\mathrm{Cl}$ & & & & $0,247^{*}$ & & \\
\hline
\end{tabular}

Примітка: 1) позначення ** - значущість зв'язку на рівні $\mathrm{p} \leq 0,01 ; *-\mathrm{p} \leq 0,05 ; 2)$ умовні позначення показників авантюрності: AvUst - установчий показник; AvEM - емоційномотиваційний показник; AvKk - когнітивний показник; AvErg - енергетичний (ергічний) показник; $\mathrm{AvKr}$ - контрольно-регулятивний показник; $\mathrm{AvOb}$ - загальний показник схильності до авантюрності; 3) умовні позначення показників вольових якостей особистості: Vp - відповідальність; In - ініціативність; Rsh - рішучість; Sm - самостійність; Np наполегливість; $\mathrm{Cl}$ - цілеспрямованість.

Показник ініціативність (In) продемонстрував лише один значимий додатній зв’язок на 5\% рівні, а, саме, з емоційно-мотиваційним показником авантюрності (AvEM). Показник рішучість (Rsh) додатньо пов'язаний з такими показниками авантюрності, як: емоційномотиваційний показник (AvEM), контрольно-регулятивний (AvKr) на 1\% рівні; 3 ергічним показником (AvErg) і загальним показником схильності до авантюрності (AvOb) - на 5\% рівні. Показник самостійність (Sm) виявив значимі додатні зв'язки на 5\% рівні з емоційномотиваційним (AvEM) i ергічним (AvErg) показниками авантюрності. Показник наполегливість (Np) додатньо пов'язаний на 5\% рівні з ергічним показником авантюрності (AvErg). Отримані результати засвідчують, що характеристиками схильності до авантюрної поведінки $є$ : ініціативність, креативність, продуктивність, лідерство, впевненість і швидкість прийняття рішення, здатність до подолання перешкод на шляху досягнення мети.

Показник цілеспрямованість (Cl) продемонстрував значимі від'ємні зв'язки 3 установчим (AvUst) i когнітивним (AvKk) показниками авантюрності на 5\% рівні. Ці результати свідчать про те, що, водночас, авантюрність супроводжується наявністю недостатньо чітких цілей та завзятості в їх досягненні.

Наступним етапом нашого емпіричного дослідження було вивчення особливостей вольових якостей особистості з різним рівнем авантюрності. 3 цією метою був використаний метод «асів» (Санникова, 1995). 3 метою відбору представників груп з високим і низьким рівнем авантюрності попередньо «сирі» бали переводилися у процентилі. Це дало нам можливість виокремити групи осіб з високим (четвертий квартіль розподілу - від 75 до 100 процентиля) значенням загального показника авантюрності та низьким значенням цього показника (перший квартіль розподілу - від 0 до 25 процентиля). Метод «профілів» (Санникова, 1995) дозволив виявити у представників цих груп середні показники, що 
характеризують їхні вольові якості. Це дозволило побудувати профіль показників вольових якостей особистості груп осіб з різним рівнем авантюрності (рис. 1).

На осі абсцис позначені показники вольових якостей особистості, на осі ординат - їх значення, що виражені у стенах. Середня лінія ряду проходить через точку 5 стен.

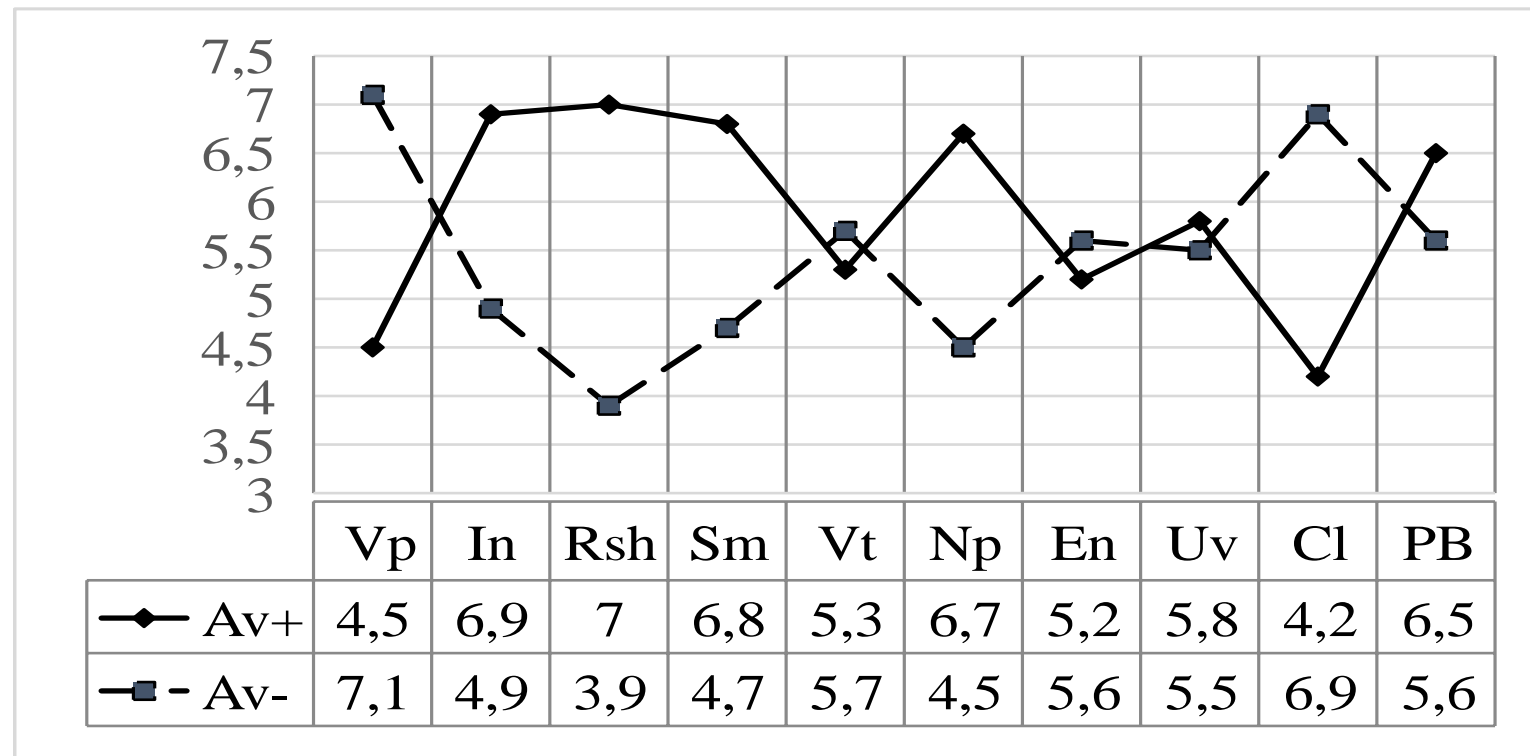

Рис. 1. Профіль показників вольових якостей особистості з різним рівнем авантюрності

Примітка: 1) група Av+ (n=13) - група осіб з високим рівнем авантюрності; група Av- (n=14) - група осіб з низьким рівнем авантюрності; 2) умовні позначення показників вольових якостей особистості: Vp - відповідальність; In - ініціативність; Rsh - рішучість; $\mathrm{Sm}$ - самостійність; Vt - витримка; Np - наполегливість; En - енергійність; Uv - уважність; $\mathrm{Cl}$ - цілеспрямованість; PB - підсумковий бал вольових якостей особистості.

Візуально профілі розташовані протилежно один до одного щодо середньої лінії ряду, що засвідчує наявність розбіжностей за більшістю показників вольових якостей особистості. Так, профіль групи осіб із високим рівнем авантюрності (група Av+) розташований переважно у додатному полюсі (в просторі третього квартілю розподілу), на відміну від профілю групи осіб з низьким рівнем авантюрності (група Av-), значення показників якого розташовані у від’ємному полюсі (переважно в просторі другого квартілю розподілу).

Для аналізу кожного профілю показники вольових якостей особистості проранжовані за їхнім відхиленням від середньої лінії ряду. Відхилення від середньої лінії ряду або до додатного чи від'ємного полюсу - це валентність. Результати ранжування подано в табл. 2.

Отже, особам з високим рівнем авантюрності (група Av+) властиві такі вольові якості особистості, як рішучість $\left(\operatorname{Rsh}^{+}\right)$, ініціативність $\left(\operatorname{In}^{+}\right)$, самостійність $\left(\mathrm{Sm}^{+}\right)$і наполегливість $\left(\mathrm{Np}^{+}\right)$. Це свідчить про те, що «авантюрні» особи швидко і впевнено приймають рішення. Вони не схильні до тривалих сумнівів, коливань під час здійснення задуманого. Проте, водночас, швидкість прийняття рішення іноді може бути викликана імпульсивністю $\left(\mathrm{Rsh}^{+}\right)$. Особам, які схильні до авантюрної поведінки, властиві ініціативність, висока креативність і продуктивність. Вони є діяльними людьми з високими лідерськими тенденціями. Вони виступають організаторами нових починань, прагнуть щось змінити. Добре проявляють себе в ситуаціях, коли зміни необхідні й потрібні новаторські підходи. Іноді, «авантюрні» особи можуть ініціювати й недостатньо продумані та ефективні новації $\left(\operatorname{In}^{+}\right)$. Представники цієї 
групи осіб прагнуть самостійно приймати рішення, можуть протистояти думці групи, якщо вона відрізняється від їх власної $\left(\mathrm{Sm}^{+}\right)$. Особи з високим рівнем авантюрності здатні до подолання перешкод на шляху досягнення своєї мети. Невдачі не вибивають їх «з колії». Вони здатні повторювати знову й знову спроби для досягнення задуманого $\left(\mathrm{Np}^{+}\right)$.

Таблиия 2

Ранжування показників вольових якостей особистості 3 високим та низьким рівнем авантюрності

\begin{tabular}{|c|c|c|}
\hline \multirow{2}{*}{ Ранг } & \multicolumn{2}{|c|}{ Групи осіб з різним рівнем авантюрності } \\
\cline { 2 - 3 } & Група Аv+ & Група Аv- \\
\hline 1 & $\mathrm{Rsh}^{+}$(рішучість) & $\mathrm{Rsh}^{-}$(нерішучість) \\
\hline 2 & $\mathrm{In}^{+}$(ініціативність) & $\mathrm{Np}^{-}$(відсутність наполегливості) \\
\hline 3 & $\mathrm{Sm}^{+}$(самостійність) & $\mathrm{Vp}^{+}$(відповідальність) \\
\hline 4 & $\mathrm{~Np}^{+}$(наполегливість) & $\mathrm{Cl}^{+}$(цілеспрямованість) \\
\hline
\end{tabular}

Примітка: показники подано у порядку зменшення абсолютних величин відхилення від середньої лінії ряду.

Особи з низьким рівнем авантюрності (група $A v$-) характеризуються наявністю таких вольових якостей особистості, як нерішучість (Rsh-), відсутність наполегливості (Np-), відповідальність $\left(\mathrm{Vp}^{+}\right)$і цілеспрямованість $\left(\mathrm{Cl}^{+}\right)$. Представники цієї групи досить нерішучі, невпевнені, схильні до постійних сумнівів. Рішення приймають після тривалих коливань і не володіють достатньою стійкістю (Rsh-). Їх можна схарактеризувати як м'яких людей. Їх деморалізують невдачі, а перешкоди часто змушують відмовитися від запланованого (Np-). «Неавантюрним» особам властиві й відповідальність, обов'язковість. Зазвичай вони старанно виконують свої обов'язки й дисципліновані $\left(\mathrm{Vp}^{+}\right)$. Ці особи мають добре усвідомлені цілі в житті. Зазвичай вони прагнуть планувати свій час і порядок виконання справ. Таким людям буває складно в ситуаціях, якщо немає об'єктивної можливості реалізації своїх цілей $\left(\mathrm{Cl}^{+}\right)$.

Отже, за допомогою проведеного якісного аналізу встановлено особливості проявів вольових якостей у «авантюрних» і «неавантюрних» осіб.

Відмінності між проявами вольових якостей в досліджуваних групах були підтверджені за допомогою непараметричного t-критерію Ст’юдента (табл. 3).

Таблиия 3

Значення t-критерію Ст'юдента між однойменними показниками вольових якостей у підвибірках, що порівнюються

\begin{tabular}{|c|c|c|c|c|c|}
\hline \multirow{2}{*}{$\begin{array}{c}\text { Група Av+ / } \\
\text { група Av- }\end{array}$} & \multicolumn{5}{|c|}{ Показники вольових якостей, що порівнюються } \\
\cline { 2 - 6 } & $\mathrm{Vp}$ & $\mathrm{In}$ & $\mathrm{Rsh}$ & $\mathrm{Sm}$ & $\mathrm{Vt}$ \\
\hline $\mathrm{t}$-критерій & $-4,295^{* *}$ & $2,941^{*}$ & $7,633^{*} * *$ & $2,843^{*}$ & $-1,19$ \\
\hline $\begin{array}{c}\text { Група Av+/ } \\
\text { група Av- }\end{array}$ & $\mathrm{5p}$ & $\mathrm{En}$ & $\mathrm{Uv}$ & $\mathrm{Cl}$ & $\mathrm{PB}$ \\
\cline { 2 - 6 } & $\mathrm{N}$ & $-1,072$ & $-0,245$ & $-9,431^{* * *}$ & 0,959 \\
\hline t-критерій & $4,064 * *$ & &
\end{tabular}

Примітка: 1) рівні значущості: позначка «*»- на значиму відмінність $(\mathrm{p} \leq 0,5)$; позначка «**» та «***» - на високу значиму відмінність $(\mathrm{p} \leq 0,01)$ та $(\mathrm{p} \leq 0,001) ; 2)$ додатний знак перед значенням t-критерія Ст'юдента означає, що цей показник за значенням вище в першій групі осіб; від’ємний знак - на більше значення показника в другій групі осіб. 
Отже, встановлено, що авантюрні особистості, порівняно з неавантюрними, більш рішучі, самостійні, ініціативні, наполегливі. Їм властиві впевненість, сміливість, рішучість, незалежність, самостійність, висока креативність, продуктивність i наполегливість у досягненні своєї мети. Водночас, неавантюрні особистості, на противагу авантюрним, більш відповідальні та цілеспрямовані. Загалом відзначимо, що в авантюрних осіб рівень свідомої регуляції поведінки більш виражений, ніж у осіб з низьким рівнем авантюрності.

\section{Висновки}

1. Теоретично встановлено, що авантюрність - це складна багаторівнева властивість особистості, психологічна сутність якої виявляється у надії на легкий і швидкий успіх, вдачу при наявності кінцевої мети, яка є принадливою для особистості, без ретельного аналізу реальних зовнішніх обставин, власних можливостей (ресурсів) і шляхів вирішення проблеми задля досягнення мети.

2. На основі якісного аналізу емпіричних даних вивчено специфіку вольових якостей особистості в «авантюрних» $\mathrm{i}$ «неавантюрних» осіб. Встановлено, що представникам певного рівня авантюрності притаманні характерні їм вольові риси особистості. Показано, що авантюрні особистості, порівняно з неавантюрними, більш рішучі, самостійні, ініціативні, наполегливі. Їм властиві впевненість, незалежність, сміливість, рішучість, самостійність, висока креативність, продуктивність і наполегливість у досягненні своєї мети. Виявлено, що неавантюрні особистості, на відміну від авантюрних, більш відповідальні та цілеспрямовані.

3. Встановлено переважно додатні значимі кореляційні взаємозв'язки між всіма показниками авантюрності й більшістю показників вольових якостей особистості, а, саме, 3 показниками рішучість (Rsh), ініціативність (In), самостійність ( $\mathrm{Sm}$ ) і наполегливість (Np). Винятком є показники відповідальність $(\mathrm{Vd})$ і цілеспрямованість $(\mathrm{Cl}), 3$ якими виявлено від'ємні значимі зв'язки.

Результати дослідження засвідчують, що в авантюрних осіб рівень свідомої регуляції поведінки, їі влади над собою більш виражений, ніж у осіб з низьким рівнем авантюрності.

Перспективи подальших досліджень полягатимуть у вивченні взаємозв'язків авантюрності із широким спектром рис особистості, вдосконалення методів психодіагностики показників авантюрності як багаторівневої властивості особистості. Особливу увагу пропонується надати розробці засобів корекції неадаптивної авантюрності та рис особистості, що супроводжують ії прояви.

\section{Література}

1. Бусел, В.Т. (Ред.) (2005). Великий тлумачний словник сучасної української мови (з дод. $i$ допов.). Київ; Ірпінь : ВТФ «Перун».

2. Евгеньев, А.П. (Ред.). (1981). Словарь русского языка: в 4-х тт. (2 изд.). ( Т.1. А-Й).

3. Жмуров, В.А. (2010). Большой толковый словарь по психиатрии. Элиста : Джангар.

4. Меленчук, Н.І. (2016). Психологічні чинники схильності особистості до авантюрної поведінки. (Дис. канд. психол. наук). Одеса.

5. Олдхэм, Дж., \& Моррис Л. (1996). Автопортрет вашей личности: Как лучше узнать самого себя. Москва : Вече, АСТ.

6. Санникова, О.П. (1995). Эмочиональность в структуре личности. Одесса : Хорс.

7. Саннікова, О.П., Санніков, О.І., \& Меленчук, Н.I. (2015). A.c. Психодіагностика авантюрності: «Тест-опитувальник схильності до авантюрності» (АВАНТ-1); «Самооиінка компонентів авантюрності», заявка № 60141; реєстрац. № 59701. 
8. Чумаков, М.В. (2006). Диагностика волевых особенностей личности. Bonpocbl психологии, 1, 169-178.

9. Чумаков, М.В. (2007). Эмоциионально-волевая регуляцุия деятельности (структура, типы, особенности функционирования в социальном взаимодействии). (Монография). Курган : Изд-во Курганского гос. ун-та.

10. Bowen, D.J., Neill, J.T., \& Crisp, S.J. (2016). Wilderness adventure therapy effects on the mental health of youth participants. Evaluation and Program Planning, 58, 49-59. doi: 10.1016/j. evalprogplan.2016.05.005.13

11. Houge Mackenzie, S., \& Brymer, E. (2020). Conceptualizing adventurous nature sport: A positive psychology perspective. Annals of Leisure Research, 23(1), 79-91. https://doi.org/10.1080/11745398.2018.1483733

12. Roth, S. (1980). Aventure et aventuriers au XVIIIe siècle. Essai de sociologie Iittéraire. Thèse, Lille. (T. 1-2).

13. Sannikova O., Melenchuk, N., \& Sannikov A. (2021). Adventurousness of personality: Construct and diagnostics. Georgian Medical News, 2(311), 109-115.

\section{References}

1. Busel, V.T. (Ed.) (2005). Velykyi tlumachnyi slovnyk suchasnoi ukrainskoi movy ( $z$ dod. $i$ dopov.) [Large explanatory dictionary of the modern Ukrainian language]. Kyiv; Irpin : VTF "Perun" [in Ukrainian].

2. Evgenev, A.P. (Ed.). (1981). Slovar' russkogo jazyka: v 4-h tt. [Dictionary of the Russian language: in 4 vols.] (2nd. ed.). (Vol. 1. A-J) [in Russian].

3. Zhmurov, V.A. (2010). Bol'shoj tolkovyi slovar' po psyhyatryy [The Big Explanatory Dictionary of Psychiatry]. Elista : Dzhangar [in Russian].

4. Melenchuk, N.I. (2016). Psykholohichni chynnyky skhylnosti osobystosti do avantiurnoi povedinky [Psychological factors of propensity of the individual to adventurous behavior]. Candidate's thesis. Odesa [in Ukrainian].

5. Oldhem, Dzh., \& Morrys, L. (1996). Avtoportret vashej lychnosty: Kak luchshe uznat' samogo sebja [Self-portrait of your personality: How to get to know yourself better]. Moscow : Veche, AST [in Russian].

6. Sannikova, O.P. (1995). Emotsionalnost'v strukture lichnosti [Emotionality in the structure of personality]. Odessa : Khors [in Russian].

7. Sannikova, O.P., Sannikov, O.I., \& Melenchuk, N.I. (2015). A.s. Psykhodiahnostyka avantiurnosti: "Test-opytuvalnyk skhylnosti do avantiurnosti" (AVANT-1); "Samootsinka komponentiv avantiurnosti" [A.s. Adventurous Psychodiagnostics: "Test-questionnaire to define the tendency to adventurism" (AVANT-1); "Self-Assessment of Adventure Components"], application № 60141; registration № 59701 [in Ukrainian].

8. Chumakov, M.V. (2006). Diagnostika volevyh osobennostej lichnosti [Diagnostics of volitional personality traits]. Voprosy psihologii-Psychology issues, 1, 169-178 [in Russian].

9. Chumakov, M.V. (2007). Jemocional'no-volevaja reguljacija dejatel'nosti (struktura, tipy, osobennosti funkcionirovanija $v$ social'nom vzaimodejstvii) [Emotional-volitional regulation of activity (structure, types, features of functioning in social interaction)]. Kurgan: Izd-vo Kurganskogo gos. un-ta [in Russian].

10. Bowen, D.J., Neill, J.T., \& Crisp, S.J. (2016). Wilderness adventure therapy effects on the mental health of youth participants. Evaluation and Program Planning, 58, 49-59. doi: 10.1016/j. evalprogplan.2016.05.005.13

11. Houge Mackenzie, S., \& Brymer, E. (2020). Conceptualizing adventurous nature sport: A positive psychology perspective. Annals of Leisure Research, 23(1), 79-91. https://doi.org/10.1080/11745398.2018.1483733 
12. Roth, S. (1980). Aventure et aventuriers au XVIIIe siècle. Essai de sociologie Iittéraire. Thèse, Lille. (T. 1-2).

13. Sannikova O., Melenchuk N., \& Sannikov A. (2021). Adventurousness of personality: Construct and diagnostics. Georgian Medical News, 2(311), 109-115.

\title{
VOLUNTARY QUALITIES OF ADVENTURE AND NON-ADVENTURE PERSONS Natalia Melenchuk \\ PhD in Psychology, Senior Lecturer of the Department of General and Differential Psychology \\ South Ukrainian National Pedagogical Ushynskyi University \\ 26, Staroportofrankivska Str., Odesa, Ukraine, 65020 \\ $\underline{\text { Natmelenchuk0808@gmail.com, http://orcid.org/0000-0002-4749-6889 }}$
}

\begin{abstract}
The theoretical analysis of the research to define such phenomena as "adventurousness", "adventure" and "adventurism" was done. Adventurousness (propensity for adventurous behavior) as a complex property of personality, is considered from the standpoint of a continuous-hierarchical approach to the structure of personality. The urgency of the problem is related to the need to study the volitional qualities and personality traits that require bold, fast, risky and adventurous actions in conditions of high uncertainty. For the empirical verification the following techniques were selected: the original psychodiagnostic "Test-questionnaire of propensity to adventure" (AVANT-1) by O. Sannikova, O. Sannikov, N. Melenchuk and the method "Volitional qualities of personality" by M. Chumakov. The results of the correlation analysis between indicators of adventurism and volitional qualities of personality traits are presented. There are mostly positive significant correlations between all indicators of adventurousness and most indicators of volitional qualities of personality: indicators of determination (Rsh), initiative ( $\mathrm{In})$, independence $(\mathrm{Sm})$ and perseverance $(\mathrm{Np})$. This is with the exceptions of responsibility $(\mathrm{Vd})$ and purposefulness $(\mathrm{Cl})$, with which there are negative significant relationships. Based on the qualitative analysis of empirical data, the specifics of volitional qualities of personality in "adventurous" and "non-adventurous" individuals have been studied. Adventurous personalities are considered to be much more decisive, independent, proactive and persistent in comparison with non-adventurous ones. They tend to show confidence, independence, courage, determination, independence, high creativity, productivity and perseverance in achieving their goals. It has been established that non-adventurous individuals, in contrast to adventurous individuals, are more responsible and purposeful. The results of the study show that the level of conscious regulation of behavior, its power over themselves is more pronounced in adventurous individuals than in individuals with a low level of adventurism.

Keywords: adventurism, tendency to adventurous behavior, volitional qualities of personality, personality trait, quantitative analysis, qualitative analysis.
\end{abstract}

